\title{
PERANCANGAN GAME KUIS INTERAKTIF SEBAGAI MULTIMEDIA PEMBELAJARAN DRILL AND PRACTICE UNTUK MENINGKATKAN HASIL BELAJAR SISWA
}

\author{
Miftah Farid Adiwisastra \\ AMIK BSI Tasikmalaya \\ Jalan Tanuwijaya No.4 Empangsari, Tawang, Tasikmalaya 46113 Indonesia \\ miftah.mow@bsi.ac.id
}

\begin{abstract}
This study aims to build a model of multimedia learning such as drill and practice that improve for student learning outcomes. The method used is us in this research is a method of research and development $(R \& D)$. Its for test the performance of the media as well as determine the feasibility of this game was tested to the field. It is hoped this game could help improve student learning outcomes. This study also aims to determine the views and interests of students towards learning using multimedia learning model of drill and practice, and to see the validity or appropriateness interactive quiz game that has been built as well as to see the students' multimedia assessment have been developed. Questionnaires were used in this study include field survey questionnaire used is given to two junior high school students of Islamic Boarding School Darul Muta'allimin Tasikmalaya and student assessment questionnaire to the interactive quiz game. In this research showed that almost all of the students gave positive responses regarding the use of multimedia learning model such as drill and practice with an interactive quiz game, students give a very good assessment of the learning multimedia interactive quiz game with a percentage rating of 91, 979\%, and get increased learning outcomes.
\end{abstract}

Keywords : Multimedia Learning, Drill and practice, Interactive Quiz Game

\begin{abstract}
Abstrak - Penelitian ini bertujuan untuk membangun multimedia pembelajaran model drill and practice untuk meningkatkan hasil belajar siswa. Metode yang digunakan dalam penelitian ini adalah metode penelitian dan pengembangan atau Research and Development $(R \& D)$. Menguji kinerja media serta mengetahui tingkat kelayakan game ini diujikan ke lapangan. Diharapkan game ini mampu membantu meningkatkan hasil belajar siswa. Penelitian ini juga bertujuan untuk mengetahui pandangan dan ketertarikan siswa terhadap pembelajaran yang menggunakan multimedia pembelajaran model drill and practice dan untuk melihat validitas atau kelayakan game kuis interaktif yang telah dibangun serta untuk melihat penilaian siswa terhadap multimedia yang telah dikembangkan. Kuisioner yang digunakan dalam penelitian ini diantaranya adalah kuisioner survey lapangan yang diberikan kepada 2 siswa SMP IBS Darul Muta'allimin Tasikmalaya dan kuisioner penilaian siswa terhadap game kuis interaktif. Dari penelitian ini didapatkan hasil yaitu hampir seluruh siswa memberikan respon positif mengenai pembelajaran yang menggunakan multimedia pembelajaran model drill and practice dengan game kuis interaktif, siswa memberikan penilaian sangat baik terhadap multimedia pembelajaran game kuis interaktif dengan persentase penilaian sebesar $91.979 \%$, dan mengalami peningkatan hasil belajar.
\end{abstract}

Kata kunci : Multimedia Pembelajaran, Drill and practice, Game kuis interaktif 


\section{PENDAHULUAN}

Perkembangan teknologi informasi dan komunikasi membawa dampak besar pada berbagai bidang kehidupan, salah satunya yaitu bidang pendidikan atau pembelajaran. Pendidikan harus memikirkan dan melaksanakan pembelajaran yang sesuai dengan kebutuhan siswa dan mengemas proses pembelajaran yang lebih bermakna, menarik, mengikuti perkembangan iptek, serta dapat membantu siswa meningkatkan prestasi belajarnya. Pada proses pembelajaran, komputer telah dilibatkan sebagai sarana pembelajaran.

Dewasa ini, telah berkembang media pembelajaran berbantukan komputer hampir dalam setiap mata pelajaran.

sebagai $\begin{array}{rlr}\text { Komputer } & \text { memiliki } & \text { peran } \\ \text { media } & \text { pembantu } & \text { atau }\end{array}$ penunjang dalam proses pembelajaran atau biasa dikenal dengan istilah Pembelajaran Berbantu Komputer atau Computer-Assisted Instruction (CAI).

Terdapat banyak model yang ditawarkan CAI, salah satu diantaranya ialah model drill and practice (berlatih dan praktek). Metode ini sangat menarik untuk dikembangkan terutama diterapkan dalam bentuk permainan atau game. Menurut Virvou teknologi game dapat memotivasi pembelajaran dan melibatkan pemain, sehingga proses pembelajaran lebih menyenangkan. Di sisi lain bahwa bermain game merupakan aktivitas yang tidak asing lagi bagi sebagian besar siswa. Bahkan tidak sedikit siswa yang bermain game merupakan hobi, sebagaimana hasil survey yang dilakukan Walsh bahwa $92 \%$ anak usia 2-17 tahun memainkan game video dan game komputer.

Bahkan menurut Carrington seperti yang diungkapkan oleh Claro bahwa diperkirakan remaja (Amerika) akan menghabiskan waktu 10.000 jam memainkan game di komputer selama ia menyelesaikan pelajaran wajib yang diterima di sekolah. Berkaitan dengan gagasan tersebut, maka penelitian ini dilaksanakan dalam rangka membuat game edukasi sebagai media bantu pembelajaran drill and practice.Game kuis interaktif merupakan perangkat lunak yang khusus didesain untuk meningkatkan hasil belajar dengan membuat latihan soal dan di sajikan dalam bentuk game dengan aturan tertentu dan diharapkan bisa dijadikan sebagai media pembelajaran yang dapat membuat proses pembelajaran menjadi lebih menarik sehingga muncul minat dan ketertarikan siswa serta sehingga dapat meningkatkan hasil belajar siswa.

\section{METODE PENELITIAN}

Metode yang digunakan dalam penelitian ini adalah metode penelitian dan pengembangan atau Research and Development $(R \& D)$ Metodologi pengembangan yang digunakan adalah metodologi yang diadaptasi dari metodologi pengembangan multimedia Mardika dan Munir, yang meliputi lima tahapan yakni tahap analisis, tahap desain, tahap pengembangan, tahap implementasi dan tahap penilaian.

\section{PEMBAHASAN}

Dari penelitian dan pengembangan yang telah dilakukan, didapatkan hasil pada tiap tahapan sesuai dengan prosedur penelitian dan pengembangan yang diuraikan sebagai berikut:

\section{Tahap Analisis}

Dalam tahapan analisis ini diuraikan sebagai berikut:

\section{Analisis Umum}

Pada tahap analisis ini, penelitian diawali dengan studi pustaka mengenai teori yang berkenaan dengan game kuis interaktif untuk didapatkan gambaran umum mengenai multimedia pembelajaran model drill and parctical games yang akan dikembangkan. Dari hasil studi pustaka, didapatkan informasi mengenai karakterisik game kuis interaktif dengan model drill and practical, diantaranya adalah sebagai berikut: game kuis interaktif dengan model drill and practical yaitu 
adanya penyajian masalah dalam bentuk latihan soal yang di kemas dalam bentuk permainan kuis dengan menjawab soal yang diajukan dengan jawaban pilhan ganda sehingga memiliki nilai pembelajaran yaitu pengetahuan yang dibutuhkan untuk menjawab soalsoal yang disajikan, memiliki sifat untuk memotivasi, mempunyai struktur dan adanya ketertarikan pancaindera dengan digunakannya gambar, animasi, dan suara.

Sementara itu, dari studi pustaka juga didapatkan bahwa terdapat hal-hal yang harus diperhatikan dalam multimedia diuraikan sebagai berikut:

1. Kemudahan navigasi

Sebuah program harus dirancang sesederhana mungkin.

2. Kandungan kognisi.

Kandungan isi program harus memberikan pengalaman kognitif (pengetahuan) yang dibutuhkan siswa.

a. Integrasi media.

$$
\text { Media }
$$

harus mengintegrasikan beberapa aspek dan keterampilan lainnya yang harus dipelajari. Seperti keterampilan berbahasa, mendengarkan, berbicara, menulis dan membaca.

b. Estetika

$\begin{array}{lcr}\text { Untuk } & \text { menarik } & \text { minat } \\ \text { pembelajar } & \text { media } & \text { harus } \\ \text { mempunyai } & \text { tampilan } & \text { yang } \\ \text { artistik. } & & \end{array}$

c. Fungsi secara keseluruhan.

\begin{tabular}{lrr}
\multicolumn{2}{c}{ Program } & yang \\
dikembangkan & harus \\
memberikan & pembelajaran \\
kepada siswa & sehingga pada \\
waktu siswa & selesai \\
menjalankan sebuah program \\
dia akan merasa & telah \\
mempelajari sesuatu.
\end{tabular}

Berkaitan dengan kriteria sebuah multimedia, survey lapangan juga dilakukan kepada siswa untuk menganalisis kebutuhan multimedia yang akan dikembangkan dilihat dari sisi pengguna. Berdasarkan survey lapangan tersebut, didapatkan hasil sebagai berikut:

1. Berkaitan dengan kemudahan navigasi, multimedia diharapkan menyediakan tautan atau tombol link yang sederhana untuk mempermudah siswa melihat materi yang diinginkan dan bersifat responsif terhadap perintah siswa.

2. Berkaitan dengan kemasan pembelajaran dalam multimedia, multimedia diharapkan bersifat interaktif, tidak membosankan, menggunakan bahasa yang mudah dipahami, dan memberikan solusi cerdas dalam memecahkan suatu permasalahan yang terdapat dalam materi.

3. Berkaitan dengan tampilan multimedia, multimedia diharapkan ditampilkan dalam bentuk yang banyak diminati dan digemari oleh siswa.

4. Berkaitan dengan pengalaman yang diinginkan siswa, multimedia diharapkan dapat memberikan pengalaman belajar menjadi lebih mudah dalam memahami sebuah materi.

5. Multimedia harus bersifat interaktif dalam artian siswa dilibatkan langsung dalam pembelajaran dengan multimedia, tidak hanya penyaji yang bertindak aktif.

6. Materi yang terkandung dalam multimedia pembelajaran adalah materi yang berhubungan dengan pelajaran.

Dari hasil studi pustaka dan survey lapangan yang dilakukan, maka didapatkan analisis kebutuhan sebagai gambaran umum untuk membangun multimedia pembelajaran game kuis interaktif. Hasil analisis kebutuhan tersebut adalah sebagai berikut:

1. Game kuis interaktif yang akan di bangun mengadaptasi tipe permainan kuis interaktif.

2. Game kuis interaktif yang akan dibangun bersifat interaktif dengan menyediakan tantangan dalam bentuk permainan pertanyaan soal- 
soal latihan yang berhubungan dengan pelajaran.

3. Game kuis interaktif yang akan dibangun dapat mengevaluasi hasil belajar siswa yaitu seberapa banyak soal-soal yang dijawab dengan benar.

4. Game kuis interaktif yang akan dibangun dapat dipasangkan dan dijalankan di komputer manapun serta mudah digunakan atau dinavigasikan.

\section{Analisis Pengguna}

Pengguna multimedia pembelajaran game kuis interaktif ini adalah siswa, mahasiswa, dan umum yang di gunakan sebagai alat bantu untuk latihan soal-soal.

\section{Analisa Perangkat Keras}

Adapun perangkat keras minimum yang di butuhkan adalah sebagai berikut:
1. Prosesor : $2.0 \mathrm{GHz}$
2. RAM $: 1 \mathrm{~GB}$
3. VGA $: 512 \mathrm{MB}$
4. Hardisk : $80 \mathrm{~GB}$

\section{Analisis Perangkat Lunak}

Dalam pembuatan multimedia pembelajaran game kuis interaktif ini dibutuhkan beberapa perangkat lunak, diantaranya:

1. Microsoft Visual Basic 6.0 di gunakan sebagai perangkat lunak utama dalam pembuatan interface dan komponen-komponen yang dibutuhkan untuk membuat game kuis interaktif.

2. Macromedia Flash 8 Professional, digunakan sebagai perangkat lunak untuk membuat animasi agar tampilan lebih menarik.

3. Adobe Photoshop, digunakan untuk melakukan pengeditan dan manipulasi pada gambar- gambar yang nantinya akan digunakan sebagai desain tampilan dan animasi.

\section{TAHAP DESAIN}

\section{Diagram Flowchart}

Untuk membangun game kuis interaktif, sebelumnya dibuat terlebih dahulu Flowchart yang akan menggambarkan urutan-urutan tampilan antarmuka pemakai pada multimedia tersebut, adapun flowchart game kuis interaktif sebagai berikut:

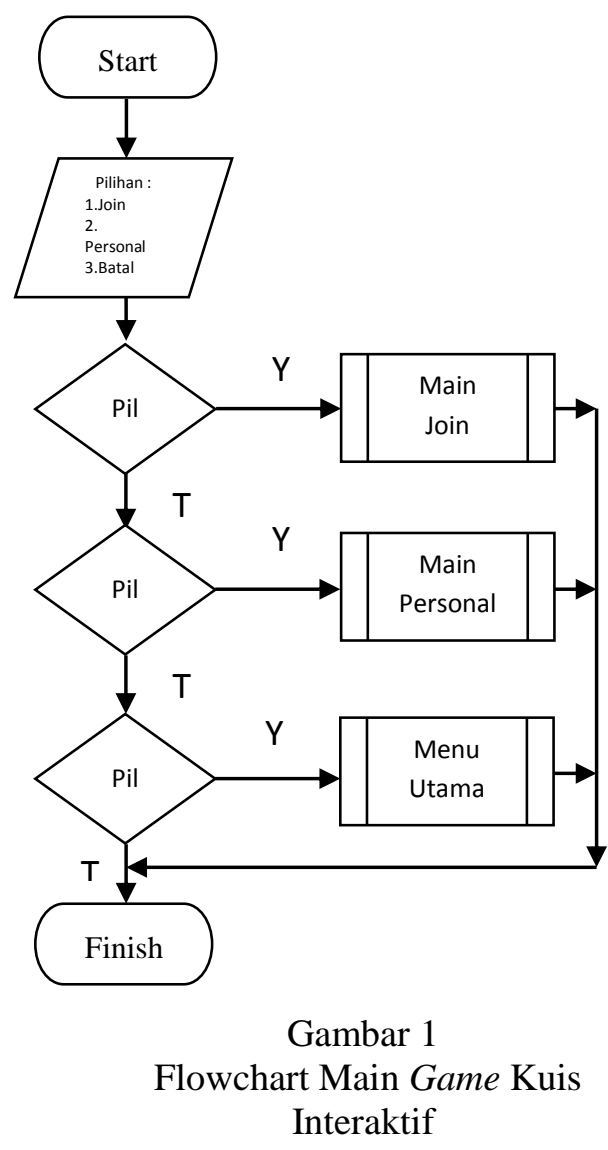

\section{Storyboard}

Perancangan storyboard ini berisi alur cerita dari game ini yang akan disajikan dalam bentuk tulisan dan gambar. Adapun storyboard untuk game kuis interaktif adalah sebagai berikut:

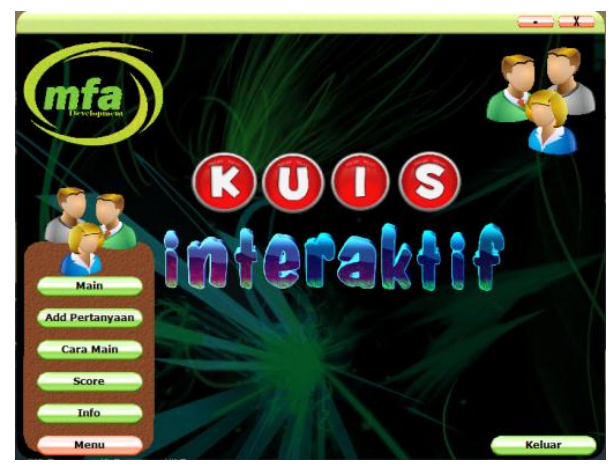

Gambar 2

Menu Utama 


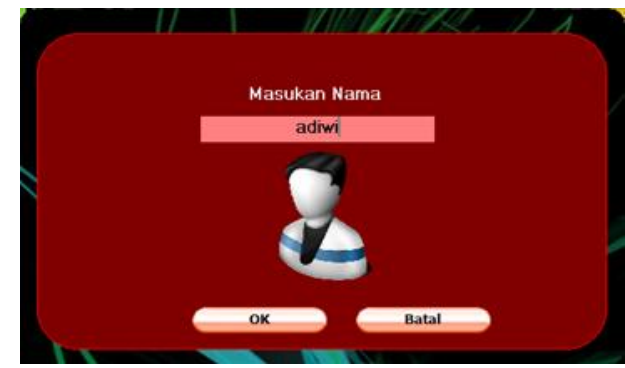

Gambar 3

Input Nama Pemain

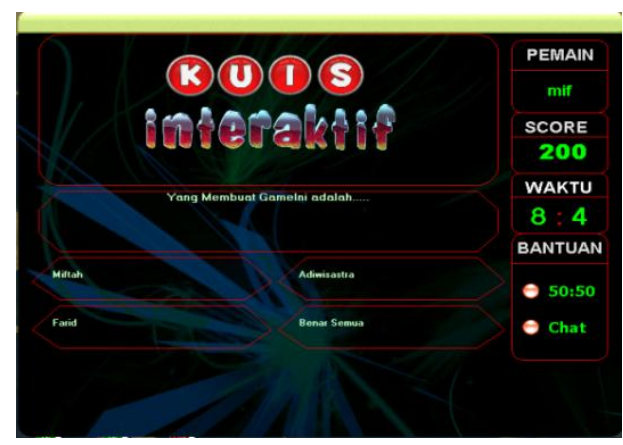

Gambar 4

Main Game Kuis Interaktif

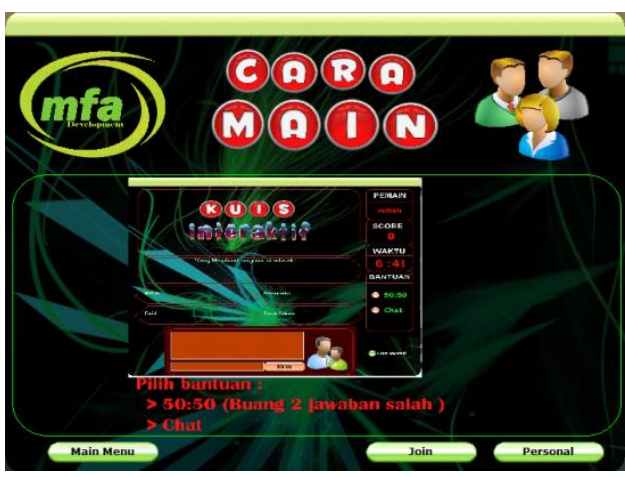

Gambar 5

Cara Main

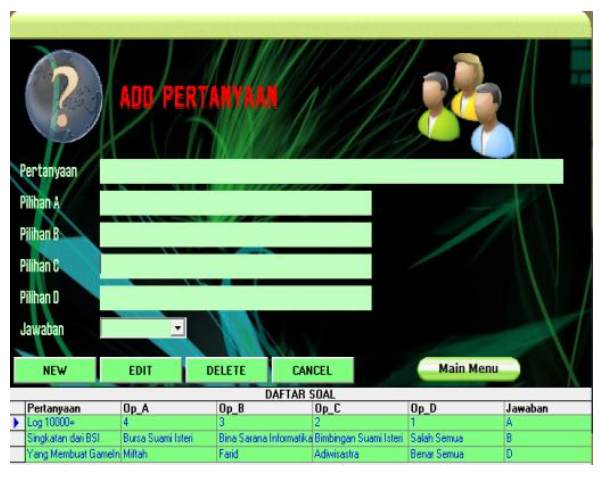

Gambar 6

Add pertanyaan

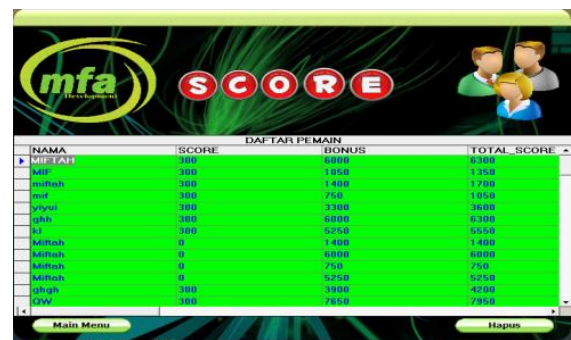

Gambar 7

Tampilan Score

Keterangan:

1. Tampilan menu utama ketika game kuis interaktif pertama di jalankan terdapat tombol menu dan keluar.

2. Klik tombol menu maka muncul menu yang bisa dipilih pengguna yaitu info, skore, cara main, add pertanyaan, dan main.

3. Animasi tulisan kuis interaktif dan animasi tombol menu ketika di klik menu tampil dan sembunyi ketika tidak di klik.

4. Klik menu main maka muncul tampilan form seperti diatas dan input nama klik tombol ok untuk memulai permainan.

5. Dua pilihan bantuan buang dua jawaban yang salah dan menanyakan teman.

6. Ketika jawaban benar maka muncul jawaban dari sistem dengan animasi tokoh kartun.

7. Suara tombol ketika diklik.

\section{Tahap Implementasi}

Tahapan selanjutnya yakni tahap implementasi dimana game kuis interaktif yang telah dihasilkan diujicobakan kepada siswa untuk memainkannya sebagai pengguna dari multimedia pembelajaran drill and practical. Uji coba ini di laksanakan di lab komputer SMP IBS Darul Muta'allimin Tasikmalaya.

\section{Pemasangan game kuis interaktif}

Pada laboraturium komputer SMP IBS Darul Muta'allimin Tasikmalay dilakukannya penelitian, terdapat 20 komputer yang memiliki spesifikasi sebagai berikut: 
1. Prosesor Intel Dual Core $2,2 \mathrm{GHz}$

2. Memori RAM $1 \mathrm{~GB}$

3. Hardisk $80 \mathrm{~GB}$

4. VGA $512 \mathrm{MB}$

Dari sisi perangkat keras, spesifikasi tersebut dinilai memadai untuk dapat menjalankan game kuis interaktif.

\section{Analisis kuisioner penilaian siswa terhadap game kuis interaktif}

Setelah menggunakan game kuis interaktif , siswa diberikan kuisioner untuk menilai game kuis interaktif dengan aspek penilaian meliputi tombol navigasi di dalam game kuis interaktif, tampilan game kuis interaktif, kemudahan penggunaan game kuis interaktif dan interaktifitas game kuis interaktif. Dari kuisioner yang diberikan, didapatkan data yang disajikan pada tabel berikut :

Tabel 1.

Rekapitulasi Kuisioner validasi Pengguna

\begin{tabular}{cccc}
\hline Aspek & Skor & Skor & Dalam \\
Penilaian & Kriteri & $\%$ \\
& & um & \\
& &
\end{tabular}

\begin{tabular}{|c|c|c|c|}
\hline \multicolumn{4}{|c|}{ Tombol navigasi di dalam game kuis interaktif } \\
\hline $\begin{array}{l}\text { Tombol navigasi } \\
\text { mudah dipahami }\end{array}$ & 104 & 120 & 86,67 \\
\hline $\begin{array}{l}\text { Tombol navigasi } \\
\text { mudah digunakan }\end{array}$ & 105 & 120 & 87,5 \\
\hline
\end{tabular}

\begin{tabular}{lccc}
\hline \multicolumn{4}{l}{ Tampilan Game Kuis Interaktif } \\
\hline $\begin{array}{l}\text { Tampilan mudah } \\
\text { dipahami }\end{array}$ & $\mathbf{1 1 0}$ & $\mathbf{1 2 0}$ & $\mathbf{9 1 , 6 7}$ \\
\hline Tampilan menarik & $\mathbf{1 0 8}$ & $\mathbf{1 2 0}$ & $\mathbf{9 0}$
\end{tabular}

\begin{tabular}{lccc}
\hline \multicolumn{3}{l}{ Kemudahan Penggunaan Game } & \multicolumn{3}{l}{ Kuis Interaktif } \\
\hline Mudah digunakan & $\mathbf{1 1 2}$ & $\mathbf{1 2 0}$ & $\mathbf{9 3 , 3 3}$ \\
\hline Nyaman digunakan & $\mathbf{1 1 1}$ & $\mathbf{1 2 0}$ & $\mathbf{9 2 , 5}$ \\
\hline \multicolumn{4}{l}{ Interaktifitas Game Kuis Interaktif } \\
\hline $\begin{array}{l}\text { Interaktifitas mudah } \\
\text { dipaham }\end{array}$ & $\mathbf{1 1 7}$ & $\mathbf{1 2 0}$ & $\mathbf{9 7 , 5}$ \\
\hline $\begin{array}{l}\text { Bersifat interaktif } \\
\text { dalam membantu } \\
\text { memahami materi yang } \\
\text { diajarkan }\end{array}$ & $\mathbf{1 1 6}$ & $\mathbf{1 2 0}$ & $\mathbf{9 6 , 6 7}$ \\
\hline
\end{tabular}

\begin{tabular}{lll}
\hline TOTAL & $\mathbf{8 8 3}$ & 960 \\
\hline
\end{tabular}

Skor kriterium atau skor maksimal adalah 24 × 8 × $5=960$. Dengan 24 merupakan responden yang mengisi angket, 8 merupakan jumlah butir pernyataan dan 5 merupakan skor tertinggi tiap butir. Jika dibandingkan antara hasil angket penilaian siswa terhadap game kuis interaktif dengan skor kriterium, maka didapatkan $883: 960=0,91979$ atau didapatkan persentase sebesar 91.979\%. Berdasarkan hal tersebut, bisa disimpulkan bahwa hampir seluruh siswa memberikan penilaian yang bisa dikategorikan Sangat Baik pada game kuis interaktif yang telah mereka gunakan.

\section{PENUTUP}

\section{Kesimpulan}

Berdasarkan hasil penelitian dan pengembangan yang telah dilalui, bisa ditarik beberapa kesimpulan sebagai berikut:

1. Penggunaan multimedia pembelajaran model drill and practice dengan game kuis interaktif dapat meningkatkan hasil belajar siswa.

2. Berdasarkan hasil kuisioner hampir seluruh siswa memberikan respon positif mengenai pembelajaran yang menggunakan multimedia pembelajaran model drill and practice, dalam konteks dapat membawa manfaat, menarik, dan bisa meningkatkan hasil belajar siswa.

\section{Saran}

Dari penelitian dan perancangan game kuis interaktif yang telah dibangun, ada beberapa saran yang ingin disampaikan peneliti diantaranya sebagai berikut:

1. Game kuis interaktif yang dihasilkan masih memiliki berbagai keterbatasan baik dalam tampilan, segi interaktifitas, dan fitur yang disediakan, oleh karena itu untuk peneliti selanjutnya yang berkenaan dengan pengembangan multimedia 
pembelajaran model drill and practice, diperlukan penelitian dan pengembangan yang lebih mendalam sehingga dihasilkan multimedia pembelajaran yang lebih interaktif, kaya akan fitur dan bermanfaat.

2. Game kuis interaktif yang dihasilkan belum diketahui efektifitas penggunaanya, maka dari itu untuk peneliti selanjutnya bisa menggunakan multimedia pembelajaran drill and practice yang telah dihasilkan untuk diteliti mengenai efektifitas penggunaannya.

\section{REFERENSI}

Arsyad, Azhar. 2007. Media Pembelajaran. Jakarta : PT. RajaGrafindo Persada.

Haryatno, Agung Hendri. (2010). Pengembangan Media Pembelajaran Interaktif Pengenalan Alat Ukur Catodhe Ray Oscilloscope (CRO) untuk Siswa SMK. Skripsi. Yogyakarta: Fakultas Teknik, Universitas Negeri Yogyakarta.

Sadiman, A. S., Rahardjo, R., Haryono, A., \& Rahardjito. $2008 . \quad$ Media Pendidikan:Pengertian,Pengemba ngan dan Pemanfaatannya. Jakarta : Rajawali Press.

Sardiman A. M. 2007. Interakasi \& Motivasi Belajar Mengajar. Jakarta : Rajawali Press.

Virvou, M. (2005). Combining Software Games with Education: Evaluation of Its Educational Effectivinnes. Journal Educational Technology and Society, 8(2), 54-65. 